\title{
TOWARD AN INTEGRATIVE HUMAN HISTORICAL SCIENCE OF THE MIND, BODY AND MATERIAL
}

\author{
Naoko MATSUMOTO \\ Okayama University, Japan
}

\begin{abstract}
Archaeology, which explores the past based on material evidence, and psychology, which analyses the modern human mind, have long been thought to be very different in both subject matter and research methods. Still, they share the ultimate aim of clarifying what it means to be human. This paper summarizes the history and current status of archaeological research on the mind and discusses how it leads to an integrative human historical science development. Successful cross-disciplinary collaboration requires us to transcend the dichotomous view that has been the basis of modern Western science. In order to understand how culture is produced through the interaction of mind and matter, we need to focus on the human body and behavior while falling into neither biological determinism nor extreme cultural relativism. The endeavor of an integral human historical science goes beyond dichotomous thinking to transcend the barriers between the humanities and the sciences and open up new dimensions in studying the human being and shed light on the nature of the phenomenon we call civilization.
\end{abstract}

Key words: cognitive archaeology, integrative human historical science, humanmaterial interaction, niche construction, civilization

\section{INTRODUCTION}

At present, 7.7 billion humans live on earth, and together with their domesticated animals, they account for more than 90 per cent of the terrestrial vertebrate biomass (BarOn et al., 2018). The amount of human-made objects may now outweigh that of all living beings on earth (Elhacham et al., 2020). This may be considered an unusual biological success of human beings. Still, it also brought us various serious problems such as environmental destruction, increasing social inequality, gender discrimination, racism, poverty and warfare. To find solutions to these problems, we need to know why humans with an inferred worldwide population of less than 10 million in 10,000 BCE have reached such an unusual "prosperity." The critical question is how the so-called civilization was created. ${ }^{1}$

'Civilization' is now considered a controversial term by many academics. It has often been used in an ethnocentric framework that places the value of modern western

This work was supported by Grant-in-Aid for Scientific Research on Innovative Areas JP19H05733 "Integrative Human Historical Science of 'Out of Eurasia."”

Correspondence concerning this article should be addressed to Naoko Matsumoto, Research Institute for the Dynamics of Civilizations, Okayama University, 3-1-1 Tsushima-naka, Kita-ku, Okayama 700-8530, Japan (e-mail: naoko_m@cc.okayama-u.ac.jp). 
society as the most advanced state. Still, I consider that the term 'civilization' is helpful as a heuristic framework for comparative analysis of the processes of the significant transformation of human lives, in which the specific characteristics which significantly separate humans from other animal behaviors, such as a large-scale and complex social structure, massive monuments, domestication of plants and animals, scientific technology, information storage, and influential religious beliefs appeared (Matsumoto, 2021).

Archaeology, which explores the past based on material evidence, and psychology, which analyses the modern human mind, have long been thought to be very different in both subject matter and research methods. Still, they share the ultimate aim of clarifying what it means to be human. We cannot truly understand how culture changes without addressing the question of the mind, nor to understand the human mind without knowing how it has evolved. To understand the human being, both a biological organism and a cultural being, we need interdisciplinary research beyond the humanities and sciences. This paper summarizes the history and current status of archaeological research on the mind and discusses how it leads to the development of an integrative human historical science that combines archaeology and psychology, which have hitherto been two completely different disciplines, as well as anthropology, philosophy, neuroscience, biology and genomics.

\section{Mind ANd Archaeology: A Brief Overview}

Throughout the history of archaeology, the question of the mind has been dealt with in different ways (Renfew \& Zubrow, 1994; Matsumoto, 2000). Some are content to apply their own motives, concepts, and beliefs to people separated by time, space, and culture; others believe studying mental aspects may be possible, but it is challenging. Some argue that it is futile even to try to reconstruct what people have thought in the past and that we should give up from the outset; others say that we should stop clinging to science and concentrate on interpretation.

In traditional culture-historical archaeology, which has continued to the present day since the birth of modern archaeology at the end of the 18th century, the classification and typology of artefacts have been the primary concern (Willey \& Sabloff, 1993). The question of cognition has often been discussed concerning the classification and typology of artefacts because any attempt to go beyond the mere construction of temporal and spatial matrices to interpretations of past cultures and societies confronts us with what causes typological variation and its transformation. If we consider artifactual variation as an expression of the cognition of the producing group, they can be a basis for reconstructing the behaviour of people in the past and, moreover, the standards, concepts and cognitive systems behind that behaviour (Rouse, 1939, 1960; Chang, 1967a, 1967b). In Western archaeology and Japanese archaeology, it has been repeatedly argued that the interest of archaeology should not be in the artifacts themselves but in the minds of the

\footnotetext{
${ }^{1}$ More information about the project can be found on the website (http://out-of-eurasia.jp/en/outline/ index.html) and in Matsumoto et al. (2021).
} 
people who made and used them (e.g., Ford, 1954; Sugihara, 1946). According to Irving Rouse, culture does not consist of artifacts but of norms or modes that govern the behaviour of its creators (Rouse, 1939). Chang argues for the possibility of discussing the nature of cognition based on material evidence stating that "even though cognitive systems are culturally determined, they do have absolute, however qualified, physical foundations. Therefore, in theory, it is always possible to recognize a cognitive system through observable physical differences by recognizing the meaningful hierarchies and contrast" (Chang, 1967b, p. 228).

Eggert criticized these ideas stating that “... students advocating the feasibility of deriving cognitive information from the archaeological record fell a victim of five major fallacies due to a misconception of scientific procedure, of the nature of archaeological data, of the concept vs. entity problem, of reality, and of the nature of prehistoric archaeology" (Eggert, 1976, p. 521). The archaeological material unearthed at the site is usually an accumulation of traces of the activities of many people over a long period. It is undoubtedly methodologically unreasonable to assume that archaeological classification of these materials represents a person's cognitive structure in the past. Attempting to reconstruct conscious categorization may not be easy for archaeology. However, it would also be inappropriate to assume that it does not involve cognitive change if there are apparent differences in making and using material culture at a particular time and region, which change in conjunction with other factors. The assumption that cognition was confined to conscious thought was a limitation of cognitive research and a point to be criticized. The dichotomous framework of discussion and the failure to address the cultural specificity and universality of cognition were also limitations of cognitive studies at this stage.

Processual archaeology, which appeared in the 1960s as a more scientific 'new archaeology,' has changed the nature of archaeology, particularly in North America. Its orientation towards explicit theoretical modelling led to a paradigm centred on an economic-functionalist approach, which actively used systems theory and computer technology (Willey \& Sabloff, 1993, p. 190). Lewis Binford, the standard-bearer of this school, severely criticized the framework of culture-historical archaeology as being 'normative' and pointed out that it was inappropriate to explain a cultural change in terms of the propagation of norms (Binford, 1965). He also argued that archaeologists should not take a psychological approach as they are not trained in palaeopsychology.

Ian Hodder, a leading figure in post-processual archaeology from the 1980s onwards, criticized the approach of processual archaeology as functionalist, ecological and materialist, and pointed out the importance of meaning as "material culture is meaningfully constituted" (Hodder, 1991, p. 1). From the perspective of the processual school, which focuses only on adaptation to the environment and functional meaning, material culture is seen as a passive reflection of the social system, and individuals as a passive entity governed by general laws. Hodder criticized the view as failing to capture the dynamic structuring process between material culture and the individual and understanding actual cultural processes (Hodder, 1991, p. 1). In contrast to the processual school, which defined archaeology as anthropology, Hodder argued for a close 
relationship with history. Meaning and action are always in a specific historical context and should be interpreted within it (Hodder, 1982, 1991). He also introduced the concept of agency of material culture as playing an active role in the production or reproduction of meaning and order rather than as a mere reflection of ideology or ideas.

Another important point made by post-processual archaeology was that archaeologists themselves are not free from the social and cultural contexts in which they find themselves (Shanks \& Tilley, 1987a, 1987b). They argued that even scientific procedures such as hypothesis-testing are historical products of modern Western civilization. All observations and interpretations depend on the ideology and theories of the society to which the researcher belongs so that there is no such thing as absolute objectivity or completely independent measurement. This relativist position has been vigorously debated (Bell, 1991; Trigger, 1989; Shanks \& Tilley, 1987a, 1987b; Binford, 1987), with fears expressed that it would undermine the objectivity and scientific nature of archaeology.

Most researchers need to be aware of their own social and cultural contexts, especially when discussing universals and specificities in culture. However, complete relativism, which assumes that all interpretations and meanings are equally arbitrary, does not stand in reality. As the Bubba/Kiki effect shows, there is a specific connection between speech sounds and visual shapes, independent of the mother tongue, which is found in infants and adults alike (Maurer et al., 2006). Thus there is no doubt that there is a certain universality in human cognition that transcends cultural differences. This is an important stepping stone for cognitive archaeology, which seeks to recover past cognition from material culture.

One solution given by post-processual archaeologists was to concentrate on contextual interpretation. Still, it is not possible to interpret the meaning of material culture in another culture without assuming some universal relationships between human cognition and material objects. The universal human nature, which is postulated as the basis for interpretation, can be imbued with the cultural specificity of the researcher. Studies of cognitive science have been rarely cited, as the relativist and humanist position of the field rejected ecological and cognitive psychological research (Shennan, 1993, p. 57). However, following the lively debate triggered by post-processual archaeology, issues of meaning and cognition have become essential themes in archaeology, leading to the development of recent interdisciplinary cognitive archaeological approaches.

\section{Development of Cognitive Archaeology}

In the 1990s, a number of books on cognitive archaeology were published (Renfrew \& Zubrow, 1994; Renfrew \& Bahn, 1996; Dark, 1995; Renfrew et al., 1993). A cognitive approach is a productive framework for more holistic archaeology based on active collaboration with related disciplines. The theories and methods used in cognitive archaeology include those derived from humanities, such as contextual analysis, phenomenology and agency, and those from more 'scientific' disciplines, such as 
cognitive science, neuroscience, and quantitative analysis. Interdisciplinary theorization is an essential feature of cognitive archaeology. In particular, the debate about the evolution of the mind has developed into a transdisciplinary field of research that links developmental psychology, clinical psychology and neuroscience (e.g., Coolidge \& Wynn, 2009; Donald, 1991; Mithen, 1996, 2005; Noble \& Davidson, 1996; Stout \& Chaminade, 2007). Mithen proposed that domain-specific intelligence developed independently during the evolution of the genus Homo and that the increased cognitive fluidity between domains gave rise to a high level of symbolic thinking of Homo sapiens, which led to uniquely human development of art, religion and science (Mithen, 1996). The triadic niche construction model is a new transdisciplinary endeavor that explains the specific mechanism of the change from domain-specific intelligence to fluid intelligence (Iriki \& Taoka, 2012; Iriki et al., 2021).

\section{Getting Over the Dialectic View}

Successful cross-disciplinary collaboration requires us to transcend the dichotomous view that has been the basis of modern Western science. The idea that body, mind, and matter (the external world) are inextricably linked has been discussed in many fields, including philosophy, anthropology, psychology, neuroscience and archaeology, where empirical and theoretical research has been carried out. Some of the concepts that have been used include embodiment, situated knowledge, tacit knowing and distributed cognition.

In archaeology, which explores the past based on material evidence, much attention has been paid to the boundaries between the material world, body and mind, and whether they can be drawn. Overcoming the dichotomous thinking such as nature/culture, material/ideal, object/subject, fact/interpretation, nonhuman/human, agency/structure, women/men, body/mind, past/present is set as the central challenge for archaeological theory in the 21 st century (Harris \& Cipolla, 2017).

Recent theories and methodologies that go beyond the dichotomy include Actornetwork theory (Latour, 2005), the debate on materiality (Furuya et al., 2017), the Material Engagement Theory (Malafouris \& Renfrew, 2010; Malafouris, 2013), and Entanglement Theory (Hodder, 2012). These theories are basically from the humanities and social sciences framework, although some refer to brain science. Actor-network theory is also a theory, but it does not explain 'why' or 'how' a network is formed; but rather, it is a way of 'describing' the relationships of matter and symbols in a network. Transdisciplinary studies and experimental research on human-material interaction are necessary to construct a model to explain the actual mechanisms of how things happen.

Research focusing on the relationship between human biology and culture is gradually increasing. Gene-culture coevolution has become one of the active research fields investigating how the human body (brain, genetics) and culture have co-evolved while mutually influencing each other (Richerson \& Boyd, 2004). The concept of "niche construction," which posits that organisms modify their immediate environments in ways 


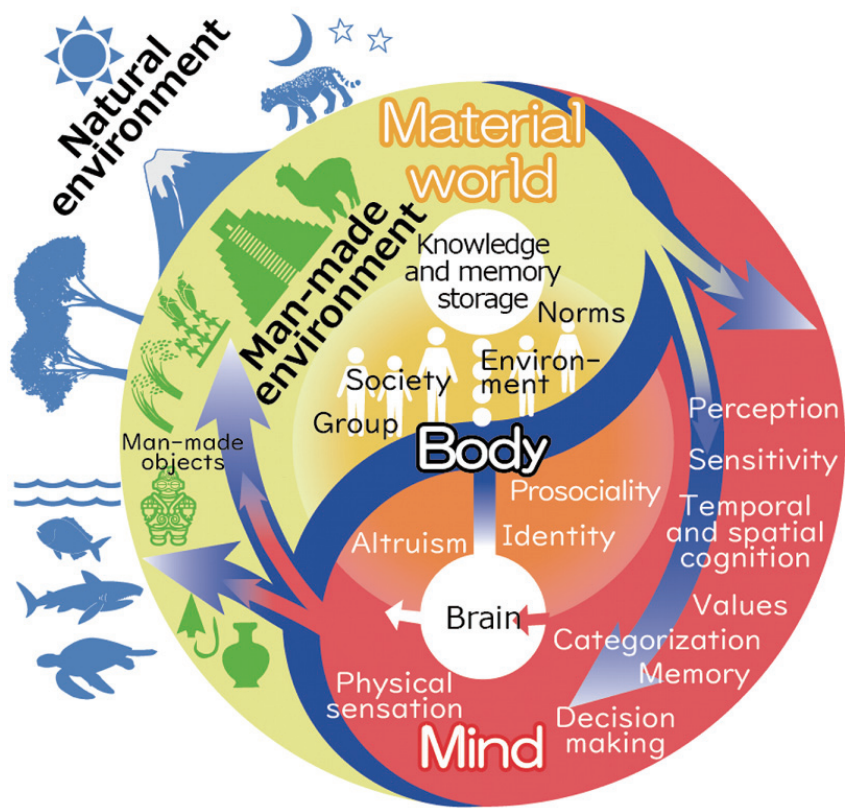

Fig. 1. Model of the Mutual Permeation of Matter and Mind as Mediated by the Body

that influence in turn the evolution of subsequent generations, has also attracted attention as a suitable explanation for human evolution (Feldman \& Zhivotovsky, 1992; Gintis, 2011; Odling-Smee et al., 2003). However, there has been little advance in understanding what happened and in what manner for the development of civilization. The reason is insufficient consideration has been made of the role played by material culture produced by humans.

In order to understand how culture is produced through the interaction of mind and matter, we need to focus on the human body and behavior while falling into neither biological determinism nor extreme cultural relativism. By taking humans as living organisms and humanly produced cultural variability as a single entity, and by overcoming the dualistic mind/body and mind/matter frameworks that have formed the basis of modern science, we can analyze the transformation of matter, mind, and body as a single, tightly integrated system. To proceed with such a perspective, we have a model of the mutual permeation of matter and mind mediated by the body as the basis of our research strategy (Fig. 1). Rather than taking individual cognition as confined within the brain, this perspective is based on lines of research on concepts such as the "embodied cognition" (Varela et al., 1991), "extended mind” (Clark \& Chalmers, 1998; Clark, 2003, 2008) and "distributed cognition" (Hutchins, 1995) which hold that cognition is inextricably related to the material world as mediated by the body. Our model also has its roots in the continuing discussion on materiality (Ingold, 2007; Knappett, 2014) and the idea of "external symbolic storage" as an indispensable part of human history (Donald, 1991; Mithen, 1998; Renfew \& Scarre, 1998). This line of argument has 
developed to the theory of material engagement; In archaeology, material culture must be analyzed not simply as a product in which the mind may be partially reflected, but rather as something which constitutes cognitive processes (Malafouris \& Renfrew, 2010; Malafouris, 2013).

The endeavor of an integral human historical science goes beyond dichotomous thinking and transcends the barriers between the humanities and the sciences and thus can bring new methods and insights to many of the participating disciplines. Through transdisciplinary research, we hope to develop a more explicit model to overcome biological determinism, which regards man's nature as genetically determined, and the position of cultural relativism, which asserts that human society and culture are independent of biological factors. This challenge has only just begun, but integrating many disciplines, with archaeology and psychology as an essential core, will open up new dimensions in studying the human being and shed light on the nature of the phenomenon we call civilization. I hope it will provide insights for creating a better world.

\section{CONFLICT OF INTEREST}

The author declares no conflicts of interest associated with this manuscript.

\section{REFERENCES}

Bar-On, Y. M., Phillips, R., \& Milo, R. (2018). The biomass distribution on Earth. Proceedings of the National Academy of Sciences, 115(25), 6506-6511. https://doi.org/10.1073/pnas.1711842115

Bell, J. A. (1991). Anarchy and archaeology. In R. W. Preucel (Ed.), Processual and postprocessual archaeology: Multiple ways of knowing the past (pp. 71-80). Southern Illinois University.

Binford, L. R. (1965). Archaeological systematics and the study of culture process. American Antiquity, 31 (2Part1), 203-210. https://doi.org/10.2307/2693985

Binford, L. R. (1987). Data, relativism and archaeological science. Man, 22(3), 391-404. https://doi.org/ $10.2307 / 2802497$

Chang, K. C. (1967a). Rethinking archaeology. Random House.

Chang, K. C. (1967b). Major aspects of the interrelationship of archaeology and ethnology. Current Anthropology, 8(3), 227-243. https://doi.org/10.1086/200795

Clark, A. (2003). Natural-born cyborgs: Minds, technologies, and the future of human intelligence. Oxford University Press.

Clark, A. (2008). Supersizing the mind: Embodiment, action, and cognitive extension. Oxford University Press.

Clark, A., \& Chalmers, D. (1998). The extended mind. Analysis, 58(1), 7-19. https://doi.org/10.1093/ analys $/ 58.1 .7$

Coolidge, F. L., \& Wynn, T. (2009). The rise of Homo sapiens: The evolution of modern thinking. WileyBlackwell. https://doi.org/10.1002/9781444308297

Dark, K. R. (1995). Theoretical archaeology. Cornell University Press.

Donald, M. (1991). Origins of the modern mind: Three stages in the evolution of culture and cognition. Harvard University Press.

Eggert, M. K. H. (1976). Prehistoric archaeology and cognitive anthropology: A review. Anthropos, 71 $(3 / 4), 508-524$. 
Elhacham, E., Ben-Uri, L., Grozovski, J., Bar-On, Y. M., \& Milo, R. (2020). Global human-made mass exceeds all living biomass. Nature, 588(7838), 442-444. https://doi.org/10.1038/s41586-020-3010-5

Feldman, M. W., \& Zhivotovsky, L. A. (1992). Gene-culture coevolution: Toward a general theory of vertical transmission. Proceedings of the National Academy of Sciences, 89(24), 11935-11938. https://doi.org/10.1073/pnas.89.24.11935

Ford, J. A. (1954). On the concept of types. American Anthropologist, 56(1), 42-57. https://doi.org/ 10.1525/aa.1954.56.1.02a00050

Furuya, Y., Seki, Y., \& Sasaki, S. (Eds.). (2017). Busshitsusei no jinruigaku [Anthropology of materiality]. Douseisha.

Gintis, H. (2011). Gene-culture coevolution and the nature of human sociality. Philosophical Transactions of the Royal Society B: Biological Sciences, 366(1566), 878-888. https://doi.org/10.1098/rstb. 2010.0310

Harris, O. J., \& Cipolla, C. (2017). Archaeological theory in the new millennium: Introducing current perspectives. Routledge. https://doi.org/10.4324/9781315713250

Hodder, I. (1982). Symbols in action. Cambridge University Press.

Hodder, I. (1991). Reading the past (2nd ed.). Cambridge University Press.

Hodder, I. (2012). Entangled: An archaeology of the relationships between humans and things. WileyBlackwell.

Hutchins, E. (1995). Cognition in the wild. MIT Press.

Ingold, T. (2007). Materials against materiality. Archaeological Dialogues, 14(1), 1-16. https://doi.org/ $10.1017 / \mathrm{S} 1380203807002127$

Iriki, A., Suzuki, H., Tanaka, S., Bretas Vieira, R., \& Yamazaki, Y. (2021). The sapient paradox and the great journey: Insights from cognitive psychology, neurobiology, and phenomenology. Psychologia, 63(2), 151-173. https://doi.org/10.2117/psysoc.2021-B017

Iriki, A., \& Taoka, M. (2012). Triadic (ecological, neural, cognitive) niche construction: A scenario of human brain evolution extrapolating tool use and language from the control of reaching actions. Philosophical Transactions of the Royal Society B: Biological Sciences, 367(1585), 10-23. https://doi.org/10.1098/rstb.2011.0190

Knappett, C. (2014). Materiality in archaeological theory. In C. Smith (Ed.), Encyclopedia of global archaeology (pp. 4700-4708). Springer. https://doi.org/10.1007/978-1-4419-0465-2_292

Latour, B. (2005). Reassembling the social: An introduction to actor-network-theory. Oxford University Press.

Malafouris, L. (2013). How things shape the mind: A theory of material engagement. MIT Press.

Malafouris, L., \& Renfrew, C. (2010). The cognitive life of things: Archaeology, material engagement and the extended mind. In L. Malafouris \& C. Renfrew (Eds.), The cognitive life of things: Recasting the boundaries of the mind (pp. 1-12). Oxbow Books.

Matsumoto, N. (2000). Ninchi kokogaku no riron to jissenteki kenkyu [Theory and practice in cognitive archaeology]. Kyushu University Press.

Matsumoto, N. (2021). Outline of the Out of Eurasia project. In N. Matsumoto, S. Sugiyama, \& C. GarciaDes Lauriers (Eds.), Proceedings of an International Conference in Mexico, February 27-28, 2020: Landscape, monuments, arts, and rituals Out of Eurasia in bio-cultural perspectives (pp. 7-13). Research Institute for the Dynamics of Civilizations, Okayama University.

Matsumoto, N., Sugiyama, S., \& Garcia-Des Lauriers, C. (Eds.). (2021). Proceedings of an International Conference in Mexico, February 27-28, 2020: Landscape, monuments, arts, and rituals Out of Eurasia in bio-cultural perspectives. Research Institute for the Dynamics of Civilizations, Okayama University.

Maurer, D., Pathman, T., \& Mondloch, C. J. (2006). The shape of boubas: Sound-shape correspondences in toddlers and adults. Developmental Science, 9(3), 316-322. https://doi.org/10.1111/j.1467-7687. 2006.00495.x

Mithen, S. (1996). The prehistory of the mind: The cognitive origins of art, religion and science. Thames and Hudson.

Mithen, S. (1998). A creative explosion? Theory of mind, language and the disembodied mind of the Upper Palaeolithic. In S. Mithen (Ed.), Creativity in human evolution and prehistory (pp. 65-191). Routledge. 
Mithen, S. (2005). The singing Neanderthals: The origins of music, language, mind and body. Weidenfeld and Nicolson.

Noble, W., \& Davidson, I. (1996). Human evolution, language and mind: A psychological and archaeological inquiry. Cambridge University Press.

Odling-Smee, F. J., Laland, K. N., \& Feldman, M. W. (2003). Niche construction: The neglected process in evolution. Princeton University Press.

Renfrew, C., \& Bahn, P. (1996). Archaeology: Theories, methods, and practice (2nd ed.). Thames and Hudson.

Renfrew, C., Peebles, C. S., Hodder, I., Bender, B., Flannery, K., \& Marcus, J. (1993). What is cognitive archaeology? Cambridge Archaeological Journal, 3(2), 247-270.

Renfrew, C., \& Scarre, C. (Eds.). (1998). Cognition and material culture: The archaeology of symbolic storage. Oxbow Books.

Renfrew, C., \& Zubrow, E. B. W. (Eds.). (1994). The ancient mind: Elements of cognitive archaeology. Cambridge University Press.

Richerson, P. J., \& Boyd, R. (2004). Not by genes alone: How culture transformed human evolution. University of Chicago Press.

Rouse, I. (1939). Prehistory in Haiti: A study in method. Yale University Publications in Anthropology 21.

Rouse, I. (1960). The classification of artifacts in archaeology. American Antiquity, 25(3), 313-323. https://doi.org/10.2307/277514

Shanks, M., \& Tilley, C. (1987a). Re-constructing archaeology: Theory and practice. Cambridge University Press.

Shanks, M., \& Tilley, C. (1987b). Social theory and archaeology. Polity Press.

Shennan, S. (1993). After social evolution: A new archaeological agenda? In N. Yoffee \& A. Sherratt (Eds.), Archaeological theory: Who sets the agenda? (pp. 53-59). Cambridge University Press.

Stout, D., \& Chaminade, T. (2007). The evolutionary neuroscience of tool making. Neuropsychologia, 45(5), 1091-1100. https://doi.org/10.1016/j.neuropsychologia.2006.09.014

Sugihara, S. (1946). Genshigaku joron [Introduction to the study of primitive period]. Ashikabi Shobo.

Trigger, B. G. (1989). Hyperrelativism, responsibility, and the social sciences. Canadian Review of Sociology and Anthropology, 26(5), 776-797.

Varela, F. J., Thompson, E., \& Rosch, E. (1991). The embodied mind: Cognitive science and human experience. MIT Press. https://doi.org/10.7551/mitpress/6730.001.0001

Willey, G. R., \& Sabloff, J. A. (1993). A history of American archaeology (3rd ed.). W. H. Freeman. 